\title{
A dual sensor device to estimate fluid flow velocity at diffuse hydrothermal vents
}

\author{
J. Sarrazin ${ }^{a}{ }^{*}$, P. Rodier ${ }^{a}$, M.K. Tivey ${ }^{b}$, H. Singh ${ }^{b}$, A. Schultz ${ }^{c}$ and P.M. Sarradin ${ }^{a}$ \\ ${ }^{a}$ Département Etude des Ecosystèmes Profonds, Laboratoire Environnement Profond, Centre Ifremer de Brest, \\ BP70, 29280 Plouzané, France \\ ${ }^{\mathrm{b}}$ Woods Hole Oceanographic Institution, Woods Hole, Massachusetts 02543, USA \\ ${ }^{c}$ College of Oceanic and Atmospheric Sciences, Corvallis, Oregon 97331-5503, USA \\ *: Corresponding author: J. Sarrazin, Tel.: +33 2982243 29; fax: +33 29822 47 57, email address : \\ Jozee.Sarrazin@ifremer.fr
}

\begin{abstract}
:
Numerous attempts have been made over the last thirty years to estimate fluid flow rates at hydrothermal vents, either at the exit of black smoker chimneys or within diffuse flow areas. In this study, we combine two methods to accurately estimate fluid flow velocities at diffuse flow areas. While the first method uses a hot film anemometer that performs high-frequency measurements, the second allows a relatively rapid assessment of fluid flow velocity through video imagery and provides in situ data to calibrate the sensor. Measurements of flow velocities on hydrothermal diffuse flow areas were obtained on the Mid-Atlantic Ridge (MAR). They range from 1.1 to $4.9 \mathrm{~mm} / \mathrm{s}$ at the substratum level, in low-temperature $\left(4.5-16.4^{\circ} \mathrm{C}\right)$ diffuse flow areas from the Tour Eiffel sulfide edifice. A strong correlation was observed between fluid flow velocities and temperature, supporting the possible use of temperature as a proxy to estimate the flow rates in diffuse flow areas where such a simple linear flow/temperature relation is shown to dominate.
\end{abstract}

Keywords: Fluid flow velocity; Hydrothermal vent; Hot film anemometer; Video imagery; Diffuse flow 


\section{Introduction}

High-temperature hydrothermal edifices at seafloor vent fields are particularly complex and dynamic, offering to organisms a variety of potential habitats that range from diffuse flow at near-ambient temperature to vigorously-venting hot smoker fluids. Fluid composition and rates of fluid flow exiting at the chimney surface vary on the same sulfide edifice, resulting in a complex mosaic of environmental conditions available for organism colonization. The distribution of vent organisms is restricted to regions where hydrothermal fluid interacts with seawater, providing both reduced and oxygenated compounds essential to microbial primary producers (Jannasch and Mottl, 1985; Childress and Fisher, 1992). The extreme dependence of vent organisms on hydrothermal fluid supply (Desbruyères et al., 1985; Tunnicliffe et al., 1990) and, conversely, the relative toxicity of these fluids (Somero et al., 1989) support a close link between the distribution of vent faunal assemblages and the characteristics of the fluids (Van Dover, 1990; Sarrazin et al., 1997; Shank et al., 1998). Most evident is a trade-off between a nutritional dependence and tolerance to harsh conditions (Chevaldonné, 2000; Shillito et al., 2001; Lee, 2003; Ravaux et al., 2003; Cosson et al., 2008).

Physico-chemical measurements of temperature, $\mathrm{pH}$, and concentrations of sulfide, methane and metals have been proposed to influence the spatio-temporal distribution of hydrothermal fauna (Johnson and Tunnicliffe, 1985; Johnson et al., 1986, 1988a,b; 1994; Fisher et al., 1988a,b; Chevaldonné et al., 1991; Shank et al., 1998; Sarrazin et al., 1999; Desbruyères et al., 2001; Luther et al., 2001; Urcuyo et al., 2003; Sarradin et al., 2008). Moreover, some authors have suggested that microhabitat variation in hydrothermal fluid flux may have an important influence on colonization by vent species (Desbruyères et al., 2000; Mullineaux et al., 2003) and also on species distribution (Sarrazin et al., 1999). Gradients of hydrothermal fluid flux may even influence successional processes at deep-sea vents (Sarrazin et al., 1997; Sarrazin et al., 1999; Sarrazin et al., 2002; Mullineaux et al., 2003).

Nevertheless, only a few attempts of quantitative fluid flow-rate measurement at the scales of vent faunal assemblages have been made (Schultz et al., 1992, 1996; Ramondenc et al., 2006). The majority of efforts have concentrated on discrete high -temperature hydrothermal discharges or on large diffuse-flow areas on the seafloor to estimate large-scale heat flow output (Corliss et al., 1979; Converse et al., 1984; Rona and Trivett, 1992; Schultz et al., 1992, 1996; Baker and Cannon, 1993; Ginster et al., 1994; Trivett and Williams, 1994; Lavelle et al., 2001; Pruis and Johnson, 2004; Ramondenc et al., 2006).

A number of different methods have been used since the discovery of vents, starting with visual observations using a vane-type flow meter from the Alvin submersible (Corliss et al., 1979). Later on, turbine flow meters combined with temperature-probe data allowed the measurement of fluid flow velocities exiting from high-temperature vents (Converse et al., 1984; Ginster et al., 1994). After calibration in the laboratory, the turbine flow meter was held $3 \mathrm{~cm}$ above the fluid exit to limit jamming of the turbine by small particles and to prevent melting of the plastic insulation. Measurements at diffuse-flow areas include those of Schultz et al. (1992); they obtained a 45-day time-series of flow rate on a diffuse flow area colonized by siboglinid tubeworms using an electromagnetic-induction flow meter that was calibrated in situ during the descent of the submersible. A later design, the MEDUSA device, was developed by Schultz et al. (1996). It measures temperature and velocity of hydrothermal effluents by means of a titanium rotor, whose spin rate is detected optically. However, it was shown that the sensor was significantly affected by fouling during long-term deployment. An alternative method, visual tracking of particles and eddies in the ascending fluids, was used by Rona and Trivett (1992) and Ramondenc et al. (2006). Both used a graduated rod placed above the vent orifice. Fluid velocity was estimated through video imagery which requires the presence of eddies and particles and does not allow for autonomous long-term measurements.

Measurement of fluid flow rate is also a challenge in cold-seep studies. As flow rates are lower and environmental constraints lighter, the sensors are based on different principles. 
For example, Linke et al. (1994) initially used a mechanical mass-flow meter (Bernoulli type) calibrated as a function of temperature, pressure and salinity. The sensor was subsequently replaced by a thermistor flow meter that can measure velocities from 0.01 to $50 \mathrm{~cm} \mathrm{~s}^{-1}$. Tryon et al. (2001) used a chemical and aqueous transport meter measuring the degree of dilution of a chemical tracer injected by an osmotic pump at a known rate. This device is capable of measuring a serial record of flow rates through the sediment surface up to $15 \mathrm{~m} \mathrm{yr}^{-1}$.

The major objective of our study was to build a reliable tool to measure fluid flow velocities on small-scale hydrothermal diffuse flow areas. We have developed a dual sensor approach to overcome harsh environmental constraints and to allow in-situ calibration. Fluid flow velocities were obtained by combining hot film anemometer measurements with visual estimates of particle ascent through video imagery. The first results using this dual sensor, obtained at the Lucky Strike vent field at $37^{\circ} 17^{\prime} \mathrm{N}$ on the Mid-Atlantic Ridge (MAR), are presented.

\section{Materials and methods}

\subsection{Fluid flow devices}

\subsection{1. a. The Flow Visualizer}

A new instrument, designed at Ifremer with the help of the Remotely Operated Vehicle (ROV) Jason engineers (Woods Hole Oceanographic Institution 1998), was developed to estimate fluid flow velocity. This "Flow Visualizer" is composed of a transparent, 2-cm interval graduated pipe mounted on a large cylindrical chamber $(300 \mathrm{~mm}$ Internal Diameter; Figure 1). Flow rate is determined by placing the device on selected diffuse-flow areas and by measuring particle ascent velocity within the pipe using video imagery. Individual particles are located by the observer, and their ascending time is recorded using the time code available on the video. Their travel distance is evaluated by using the 2-cm-spaced graduations of the pipe. The observer records the time that it takes for each visible particle to reach the top of the cylinder.

The variability due to the observer was examined with two Wilcoxon signed ranked tests for paired samples (Table 1). Because several particles are regularly passing through the graduated tube, each observer does not necessarily select the same ones. The first test was done to evaluate difference in the mean velocity measured by two observers between different video sequences, regardless of the particles chosen. The second was done to assess difference in the measured velocity for common particles between two observers. The specific particles every observer measured were identified by noting the time each particle entered the flow tube. This was done for three paired data sets (OBS1 vs. OBS2, OBS1 vs. OBS3 and OBS2 vs. OBS3), testing three different observers.

\subsection{2. b. The flow sensor}

The heated thin film flow sensor used (Figure 2) was delivered by Earth-Ocean Systems Ltd. The sensor is a Constant Voltage Anemometer type (CVA). This device employs two thin-film Pt resistive temperature sensors and a precision surface-mount resistor used as a heating element, contained within a paddle made of epoxy. The voltage applied to the heating element is constant. The sensor is immersed in the hydrothermal effluent. The upstream temperature sensor measures the ambient temperature ( $\mathrm{Ta}$ ), whereas the second, coupled thermally to the heater, measures the hot film temperature (Tw). The difference between $\mathrm{Ta}$ and Tw is proportional to the effluent flow rate, reflecting the increasing quantity of heat advected away from the thermal sensors in proportion to the increasing flow rate of the effluent. 


\subsection{3. c. Dual system - The FLO}

The Flow Visualizer and the flow sensor were combined in a single instrument, named FLO, to perform a cross-comparison of the two methods. The dual system is composed of a transparent 2-cm graduated tube mounted on a chamber (Figure 1). A honeycomb material consisting of cells that are $3 \mathrm{~mm}$ in diameter was placed inside the chamber to regularize the flow regime. The flow sensor was set at the base of the tube in an elliptical nozzle. A flexible rubber skirt was used to seal the bottom of the chamber and limit leakage when the instrument was deployed on irregular surfaces. The size and shape of all of the elements composing the FLO were determined according to hydrodynamic constraints. The objective was to obtain a laminar (no turbulence) and uniform (flat velocity profile) flow at the sensor level. First of all, the pipe inner diameter $(50 \mathrm{~mm})$ was determined by the sensor size. To avoid disturbance at the measurement level, the length of the pipe was set at $500 \mathrm{~mm}$ to reach 10 times the inner diameter. The nozzle, mounted between the pipe and the chamber, insures a flat velocity profile. The ratio between the diameter of the chamber and that of the pipe (6:1) was calculated to amplify the velocity values obtained by the sensor (sensitivity gain). Therefore, to obtain the velocities at the substratum level, the results have to be divided by 37.6. The honeycomb layer was placed at $150 \mathrm{~mm}$, which corresponds to half the chamber diameter, to insure a homogeneous flow at the nozzle inlet (Figure 1). The honeycomb should not have any hydrodynamic influence except for regulating the flow. The data-logger and battery are included in a titanium housing, rated up to $6000 \mathrm{~m}$.

The FLO is deployed by the manipulator arm of a ROV on a targeted sampling area (Figure 3 ). The instrument must be placed on a relatively flat surface, and the pipe has to be vertical (more or less $10^{\circ}$ ). Once the instrument is set, the ROV main camera is focused and video imagery of the fluids ascending through the pipe is recorded for a few minutes. The sampling time was optimized to 10 minutes per sampling area for the MoMARETO cruise (2006). The FLO can work autonomously for up to 24 hours.

\subsection{Modeling the sensor response}

To characterize the relationship between fluid flow velocity $(U)$, fluid temperature $(\mathrm{Ta})$ and the hot film temperature (Tw), the formula of a Constant Voltage Anemometer (CVA) (King 1914) is used.

(eq. 1)

$$
f(U)=A+B \cdot U^{n}
$$

Where $U$ is flow velocity, and $A, B$ and $n$ are constants.

The PDR method, ratio of Power dissipated in hot-wire to the Difference in the Resistance (Sarma \& Comte-Bellot, 2002; Truzzi et al. 2002) states that:

$$
\frac{P_{w}}{\left(R_{w}-R_{a}\right)}=A+B \cdot U^{n}
$$

$$
\text { with: } P_{w}=\frac{E_{w}{ }^{2}}{R_{w}}
$$

where Pw is the power dissipated in the heating element, Ew is the constant voltage applied to the hot-wire, Rw is the resistance of the heating element and $\mathrm{Ra}$ is the resistance in ambient conditions. The two equations become:

$$
U^{n}=\left(\frac{E_{w}{ }^{2}}{B}\right) \cdot \frac{R_{w}{ }^{-1}}{R_{w}-R_{a}}-\left(\frac{A}{B}\right)
$$

Since the sensor resistances are temperature dependent, the wire temperature $T_{w}$ and the fluid temperature $T_{a}$ are implicitly represented through $R_{w}$ and $R_{a}$. The other terms of the formula are constants, so we may set $C=E_{w}{ }^{2} / B$ and $D=-A / B$. Then equation $3 a$ can be written as: 
(eq. 3b)

$$
U^{n}=C \cdot \frac{T_{w}^{-1}}{T_{w}-T_{a}}+D
$$

This theoretical equation was empirically transformed to better match the sensor response obtained in our experimental design. Therefore, the best curve fit is obtained with $n=1$ and by applying a power law $(\mathrm{m})$ to the ratio of $T_{w}$ over the temperature compensation term $\left(T_{w}-T_{2}\right)$. With these modifications, the response model of our sensor becomes:

$$
U=C^{\prime} \cdot \frac{T_{w}}{\left(T_{w}-T_{a}\right)^{m}}+D^{\prime}
$$

with $C^{\prime}, D^{\prime}$ and $m$ as calibration constants.

In order to find these calibration constants, we used a specifically designed calibration device (an upside down version of the FLO; Figure 4). The calibration device uses Bernoulli \& Torricelli gravity principles. It consists of a plane-parallel water tank regulated at a constant level by an overflow pipe (Figure 4). The flow sensor is inserted at the entrance of the outlet pipe. The flow is calmed upstream of the sensor by a honeycomb structure and regulated downstream by a needle valve. The geometry of the calibration device has been calculated to limit hydrodynamic disturbances as for the FLO instrument. The flow rate is calculated by recovering and weighing the water passing through the system during a measured period. The velocity is then deduced by dividing the flow rate by the cross sectional area at the sensor level. Temperatures are obtained by the calibrated flow sensors. A series of regulated ambient temperatures ( $\mathrm{Ta}: 17.5$ to $\left.35.3^{\circ} \mathrm{C}\right)$ and flow velocities $\left(18 \mathrm{~mm} \mathrm{~s}^{-1}\right.$ to $\left.160 \mathrm{~mm} \mathrm{~s}{ }^{-1}\right)$ were used to obtain the different response curves (Figure 5). The coefficients $C^{\prime}, D^{\prime}$ and $m$, which are sensor-specific, are estimated using the Marquardt non-linear regression method (Statgraphics Plus software $\subset$ version 5.1). For the sensor used to generate the response curves in Figure 5, we found:

$$
U=875.712 \cdot \frac{T_{w}}{\left(T_{w}-T_{a}\right)^{3.24614}}-3.84287
$$

This equation describes the curves seen in Figure 5 and the results from the calibration give the data shown in Figure 6. Calibration coefficients can also be determined in the field, using velocity measurements from video imagery as a reference.

\subsection{At-sea trials}

The first in-situ use of the FLO was carried out during the EXOMAR cruise on the RV L'Atalante with the ROV Victor6000 (2005) on the Tour Eiffel edifice located within the Lucky Strike vent field on the Mid-Atlantic Ridge. Four trials were done allowing validation of the system deployment by the ROV, refinement of the method, and the acquisition of two series of data using the visual approach only (because of failure of the sensor).

The second use of the FLO, with a new sensor that was calibrated in the field, was during the MoMARETO cruise (R/V Pourquoi pas?/ROV Victor6000, Sarrazin et al., 2006). The system was deployed during four dives on the same sulfide edifice (Figure 3 ). In addition to the temperature taken by the flow sensor $(\mathrm{Ta})$, ambient seawater temperature measurements were acquired with the ROV's temperature probe and with autonomous probes (NKE®, France). All data sets (video, temperature) were synchronized with the Victor6000 internal clock. 


\section{Results}

\subsection{Observer effect}

Six to nine video sequences from three dives were analyzed. Results of the first Wilcoxon test show that the mean velocity estimates from OBS3 was statistically different from that of the two others when using all data available (Table 1). Results of the second Wilcoxon test for particle velocities showed that no statistical difference between the three observers is observed when using the same particles (Table 1). These results validated the robustness of the visual method to evaluate particle speed regardless of the observer. The differences observed in the first test were probably due to difference in particle selection between the three observers. An optimal protocol would take the mean of velocity estimates obtained by two or more observers, regardless of the particles they choose. This will lead to better estimates of the fluid velocities observed in the field.

\subsection{Data acquisition and sensor post-calibration}

Fourteen data sets, coupling sensor measurements and video imagery, were obtained and processed. The two temperature probes $\left(T_{a}\right.$ and $\left.T_{w}\right)$ were calibrated on board. The data were acquired every five seconds. The duration of a measurement, gathering both video and sensor data, varied from 0.5 to 10 minutes per sampling site. No leakage was observed at the base of the FLO skirt during these measurements. Unfortunately, the video images were only usable for 8 of 14 deployments. On the other sequences, the amount of particles was insufficient to obtain reliable data. In addition, sensor data were lost because of power failure during dive 305.

The calibration of the new sensor was done using the velocity measurements from video imagery as reference. The coefficients of equation 4 for the new sensor, calibrated in the field, were found by combining ambient temperature $\left(T_{a}\right)$, hot film temperature $\left(T_{w}\right)$ and fluid flow velocity estimated from video imagery. The mean temperature values $\left(T_{a}\right.$ and $\left.T_{w}\right)$ were calculated from the stabilized part of the sequence (see example in Figure 7 ). The resulting equation, giving the flow velocity $\mathrm{U}$, measured by the flow sensor becomes:

$$
U=16.3399 \cdot \frac{T_{w}}{\left(T_{w}-T_{a}\right)^{0.230206}}-60.5588
$$

The differences in calibration coefficients (equations 5 and 6) are due to the use of two slightly different sensors.

The sensor flow velocity was calculated for all data sets, including the deployments where no video was available (Table 2). The flow rate was deduced from the sensor flow velocity using the internal dimensions of the FLO structure $\left(30 \mathrm{~cm}\right.$ skirt diameter and thus $706.9 \mathrm{~cm}^{2}$ area at the base of the FLO structure and $18.8 \mathrm{~cm}^{2}$ free section at sensor level).

\subsection{Temperature and velocity data}

The ambient temperature $\left(T_{a}\right)$ measured in the diffuse flow areas ranges between 4.5 and $16.4^{\circ} \mathrm{C}$ for a surrounding seawater temperature of $4.4^{\circ} \mathrm{C}$. The hot film temperature $\left(T_{w}\right)$ varied from 8.7 to $20.0^{\circ} \mathrm{C}$. The flow velocities extracted from video analyses and used for calibration varied from 56.8 to $161.5 \mathrm{~mm} \mathrm{~s}^{-1}$, and the calculated flow velocities, extracted from the sensor data, varied from 41.9 to $183.6 \mathrm{~mm} \mathrm{~s}^{-1}$ at the sensor level and from 1.1 to 4.9 $\mathrm{mm} \mathrm{s}^{-1}$ at the substratum level (Table 1). The calculated flow rates extend from 66.2 to $293 \mathrm{~L}$ $\mathrm{min}^{-1} \mathrm{~m}^{-2}$. Figure 7 gives an example of the fluid velocity data obtained during the fourth deployment of dive 304 . 


\section{Discussion/conclusion}

Within hydrothermal vent fields, the distribution of faunal assemblages may be influenced significantly by small-scale variations in fluid flow (Schultz et al., 1992; Sarrazin and Juniper, 1999). In this study, we combine two methods to accurately estimate fluid flow rates on diffuse flow areas. The first uses a heat-flow sensor, and the second measures fluid flow rates with visual estimates of particle ascent through video imagery. They are complementary: whereas the visual technique allows a relatively rapid assessment of fluid flow velocity, the flow sensor performs high-frequency measurements and provides temperature data. Nevertheless, the use of this sensor is sensitive to environmental temperature changes because its principle is based on temperature measurements. The dual approach is a convenient means to overcome this limitation by using video imagery to acquire discrete fluid-velocity estimates for post-calibration.

The dual approach used in this study allowed us to gather reliable measurements of flow velocities on a hydrothermal edifice on the mid-Atlantic ridge. Comparisons with other studies remain difficult because the measurement methods vary (direct versus indirect) and only a few measurements consider the surface studied (Table 3). Ideally, to be comparable, fluid velocity and fluid flow rate data should take the surface into account and include a detailed description of the type of fluid emissions (discrete versus diffuse).

Our measured flow velocities (at the sensor level) fall within the ranges observed by Rona and Trivett (1992) and Ramondenc et al. (2006) at low-temperature diffuse venting sites (Table 3). Nevertheless, these data do not inform about the emissions at the substratum level, reflecting the conditions experienced by the fauna. Data at the substratum level are scarce. Those obtained by Schultz et al. (1996) in a single diffuse flow site at TAG (MidAtlantic Ridge) give a particularly weak fluid velocity for a quite constant temperature (Table 3). The discrete velocity data obtained within this study at the substratum level are comparable. Nevertheless, they differ greatly from those found in diffuse flow sites from the Juan de Fuca Ridge (Schultz et al. 1992), highlighting the heterogeneity of the vent environments. Moreover, measured flow rates from high-temperature exits can be up to 30 times higher than flow rates obtained in diffuse flow sites (Table 3).

One notable result of this study is the strong linear relationship between the ambient temperature and the flow rate in low-temperature areas $\left(4.7-16.4^{\circ} \mathrm{C}\right.$, Figure 8$)$. This correlation is in accordance with the buoyant plume theory mentioned by Schultz et al. (1992) for sites where diffuse hydrothermal fluids are of shallow, near-seafloor origin. According to this theory, the flow dynamics of such fluids should be governed primarily by the buoyancy of hot fluids rather than by poroelastic Darcy flow. Additional measurements are now required to corroborate the data acquired during this study and to refine the relationship between fluid flow velocity and temperature over a larger range and at variable tide cycles.

In areas where the relationship between temperature and flow velocity is verified, temperature can be used as a proxy to estimate fluid flow rates within different faunal assemblages. Thus, not only temperature may be used as a key-parameter to estimate the chemical composition of the fluids (Sarradin et al., 2008) but also other factors linked to fluid flow rates that could be of ecological significance. Nevertheless, while the FLO may be useful for measuring fluid flow rate in most hydrothermal communities (alvinellid, gastropod and mussel assemblages), it would require a major adaptation to measure fluid flow in long tube worm communities. Ultimately, the energy budget required to sustain chemosynthetic processes within different faunal assemblages could be estimated through extrapolation of discrete flow-rate measurements (Martins et al., 2008). 


\section{Acknowledgements}

We would like to thank the captain Philippe Guillemet of the R/V Pourquoi pas? and his crew for their essential collaboration to the success of the MoMARETO cruise. We also acknowledge the Victor6000 pilots for their patience and constant support. Part of this cruise was funded by the EXOCET/D European project, contract \# GOCE-CT-2003-505342. The dual system was first tested during the EXOMAR cruise (2005) led by Anne Godfroy (Ifremer). As this work was initiated in Woods Hole, we would like to thank the ROV pilots of Jason who helped design the flow visualizer. We are particularly thankful to Andy Bowen, Will Sellers and Matt Heintz for their help building the flow visualizer, to Dan Fornari for his help and advice with the Vemco probes, to Gene Terray for good conversation about fluid dynamics and to Olivier Gauthier for the great statistical help. The first part of this research was sponsored by a NOAA/NURP grant award \#NA96RU0221 and NSF grant OCE-9901563 to MKT and JS. JS was also supported by a FCAR (Quebec) post-doctoral fellowship. The last part of the project was supported through the ANR DEEP OASES (ANR06 BDV005).

\section{References}

Baker, E.T., Cannon, G.A., 1993. Long-Term Monitoring Of Hydrothermal Heat-Flux Using Moored Temperature Sensors, Cleft Segment, Juan de Fuca Ridge. Geophys. Res. Lett. 20 (17), 1855-1858.

Chevaldonné, P., Desbruyères, D., Le Haître, M., 1991. Time-series of temperature from three deep-sea hydrothermal vent sites. Deep-Sea Res. 38 (11), 1417-1430.

Chevaldonné, P.F., C.R. Childress J.J. Desbruyères, D. Jollivet, D. Zal, F. Toulmond, A., 2000. Thermotolerance and the "Pompeii worms". Mar. Ecol. Prog. Ser. 208, 293-295.

Childress, J.J., Fisher, C.R., 1992. The biology of hydrothermal vent animals: physiology, biochemistry and autotrophic symbioses. In: Barnes, M., A.D. Ansell, Gibson, R.N. (Eds.), Oceanogr. Mar. Biol. Ann. Rev. UCL press, pp. 337-441.

Converse, D.R., Holland, H.D., Edmond, J.M., 1984. Flow rates in the axial hot springs of the East Pacific Rise $\left(21^{\circ} \mathrm{N}\right)$ : implications for the heat budget and the formation of massive sulfide deposits. Earth Planet. Sci. Lett. 69, 159-175.

Corliss, J.B., Dymond, J., Gordon, L.I., Edmond, J.M., Von Herzen, R.P., Ballard, R.D., Green, K., Williams, D., Bainbridge, A., Crane, K., Van Andel, T.H., 1979. Submarine thermal springs on the Galapagos rift. Science 203 ( $\left.n^{\circ} 4385\right), 1073-1083$.

Cosson, R.P., Thiébaut, É., Company, R., Castrec-Rouelle, M., Colaço, A., Martins, I., Sarradin, P.-M., Bebianno, M.J., 2008. Spatial variation of metal bioaccumulation in the hydrothermal vent mussel Bathymodiolus azoricus. Mar. Env. Res. 65 (5), 405.

Desbruyères, D., Gaill, F., Laubier, L., Fouquet, Y., 1985. Polychaetous annelids from hydrothermal vent ecosystems: an ecological overview. Biol. Soc. Wash. Bull. 6, 103-116.

Desbruyères, D., Almeida, A., Biscoito, M., Comtet, T., Khripounoff, A., Le Bris, N., Sarradin, P.M., Segonzac, M., 2000. A review of the distribution of hydrothermal vent communities along the Northern Mid Atlantic Ridge: Dispersal versus environmental controls. Hydrobiol. 440, 201-216.

Desbruyères, D., Biscoito, M., Caprais, J.C., Colaço, A., Comtet, T., Crassous, P., Fouquet, Y., Khripounoff, A., Le Bris, N., Olu, K., Riso, R., Sarradin, P.M., Segonzac, M., Vangriesheim, A., 2001. Variations in deep-sea hydrothermal vent communities on the MidAtlantic ridge near the Azores plateau. Deep-Sea Res. 48, 1325-1346.

Fisher, C.R., Childress, J.J., Arp, A.J., Brooks, J.M., Distel, D., Favuzzi, J.A., Felbeck, H., Hessler, R., Johnson, K.S., Kennicutt II, M.C., Macko, S.A., Newton, A., Powell, M.A., Somero, G.N., Soto, T., 1988a. Microhabitat variation in the hydrothermal vent mussel, Bathymodiolus thermophilus, at the Rose Garden vent on the Galapagos Rift. Deep-Sea Res. 35, 1769-1791. 
Fisher, C.R., Childress, J.J., Sanders, N.K., 1988b. The role of vestimentiferan hemoglobin in providing an environment suitable for chemoautotrophic sulfide oxidizing endosymbionts. Symbiosis 5, 229-246.

Ginster, U., Mottl, M.J., Vonherzen, R.P., 1994. Heat-Flux From Black Smokers On The Endeavor And Cleft Segments, Juan-De-Fuca Ridge. J. Geophys. Res. 99 (B3), 4937-4950.

Jannasch, H.W., Mottl, M.J., 1985. Geomicrobiology of deep-sea hydrothermal vents. Science 229, 717-725.

Johnson, H.P., Tunnicliffe, V., 1985. Time-series measurements of hydrothermal activity on northern Juan de Fuca Ridge. Geophys. Res. Lett. 12, 685-688.

Johnson, K.S., Beelher, C.L., Sakamoto-Arnold, C.M., Childress, J.J., 1986. In situ measurements of chemical distributions in a deep-sea hydrothermal vent field. Science 231, 1139-1141.

Johnson, K.S., Childress, J.J., Beelher, C.L., 1988a. Short time temperature variability in the Rose Garden hydrothermal vent field: an unstable deep sea environment. Deep-Sea Res. 35, 1711-1721.

Johnson, K.S., Childress, J.J., Beelher, C.L., Sakamoto, C.M., 1994. Biogeochemistry of hydrothermal vent mussel communities: the deep sea analogue to the intertidal zone. Deep Sea Res. 41, 993-1011.

Johnson, K.S., Childress, J.J., Hessler, R.R., Sakamoto-Arnold, C.M., Beelher, C.L. 1988b. Chemical and biological interactions in the Rose Garden hydrothermal vent field, Galapagos spreading center. Deep-Sea Res. 35, 1723-1744.

King, L. V. 1914. On the convection of heat from small cylinders in a stream of fluid: Determination of the convection constants of small platinium wires with applications to hotwire anemometry. Phil. Trans. Roy Soc. A214, pp. 373-432.

Lavelle, J.W., Wetzler, M.A., Baker, E.T., Embley, R.W., 2001. Prospecting for hydrothermal vents using moored current and temperature data: Axial Volcano on the Juan de Fuca Ridge, northeast Pacific. J. Phys. Oceanogr. 31 (3), 827-838.

Lee, R.W., 2003. Thermal Tolerances of Deep-Sea Hydrothermal Vent Animals From the Northeast Pacific. Biol. Bull. 205 (2), 98-101.

Linke, P., Suess, E., Torres, M., Martens, V., Rugh, W.D., Ziebis, W., Kulm, L.D., 1994. In situ measurement of fluid flow from cold seeps at active continental margins. Deep Sea Res. $41,721$.

Luther, G.W., Rozan, T.F., Taillefert, M., Nuzzio, D.B., Meo, C.D., Shank, T.M., Lutz, R.A., Cary, S.C., 2001. Chemical speciation drives hydrothermal vent ecology. Nature 410, 813816.

Martins, I., Colaço, A., Dando, P.R., Martins, I., Desbruyères, D., Sarradin, P.-M., Marques, J.C., Serrão-Santos, R., 2008. Size-dependent variations on the nutritional pathway of Bathymodiolus azoricus demonstrated by a C-flux model. Ecol. Model. 217 (1-2), 59.

Mullineaux, L.S., Peterson, C.H., Micheli, F., Mills, S.W., 2003. Successional mechanism varies along a gradient in hydrothermal fluid flux at deep-sea vents. Ecol. Monogr. 73 (4), 523-542.

Pruis, M.J., Johnson, H.P., 2004. Tapping into the sub-seafloor: examining diffuse flow and temperature from an active seamount on the Juan de Fuca Ridge. Earth Planet. Sci. Lett. 217 (3-4), 379-388.

Ramondenc, P., Germanovich, L.N., Von Damm, K.L., Lowell, R.P., 2006. The first measurements of hydrothermal heat output at $9^{\circ} 50^{\prime} \mathrm{N}$, East Pacific Rise. Earth Planet. Sci. Lett. 245 (3-4), 487.

Ravaux, J., Gaill, F., Bris, N.L., Sarradin, P.-M., Jollivet, D., Shillito, B., 2003. Heat-shock response and temperature resistance in the deep-sea vent shrimp Rimicaris exoculata. J. Exp. Biol. 206 (14), 2345-2354.

Rona, P.A., Trivett, D.A., 1992. Discrete and diffuse heat transfer atashes vent field, Axial Volcano, Juan de Fuca Ridge. Earth and Planetary Science Letters 109 (1-2), 57.

Sarma, Garimella R., Comte-Bellot, G. 2002. Automated constant voltage anemometer for measurements with fluid temperature drifts. Rev. Sci. Instr. 73, n 3, pp. 1313-1317. 
Sarradin, P.-M., Lannuzel, D., Waeles, M., Crassous, P., Le Bris, N., Caprais, J.C., Fouquet, Y., Fabri, M.C., Riso, R., 2008. Dissolved and particulate metals (Fe, Zn, Cu, Cd, Pb) in two habitats from an active hydrothermal field on the EPR at $13^{\circ} \mathrm{N}$. Sci. Tot. Env. 392 (1), 119129.

Sarrazin, J., Robigou, V., Juniper, S.K., Delaney, J.R., 1997. Biological and geological dynamics over four years on a high-temperature sulfide structure at the Juan de Fuca Ridge hydrothermal observatory. Mar. Ecol. Prog. Ser. 153, 5-24.

Sarrazin, J., Juniper, S.K., 1999. Biological characteristics of a hydrothermal edifice mosaic community. Mar. Ecol. Prog. Ser. 185, 1-19.

Sarrazin, J., Juniper, S.K., Massoth, G., Legendre, P., 1999. Physical and Chemical factors influencing species distributions on hydrothermal sulfide edifices of the Juan de Fuca Ridge, Northeast Pacific. Mar. Ecol. Prog. Ser. 190, 89-112.

Sarrazin, J., Levesque, C., Juniper, S.K., Tivey, M.K., 2002. Mosaic community dynamics on Juan de Fuca Ridge sulfide edifices: substratum, temperature and implications for trophic structure. Cah. Biol. Mar. 43, 275-279.

Sarrazin, J., Sarradin, P.M. and MoMARETO cruise participants., 2006. MoMARETO: a cruise dedicated to the spatio-temporal dynamics and the adaptations of hydrothermal vent fauna on the Mid-Atlantic Ridge. InterRidge News 15, 24-33.

Schultz, A., Delaney, J.R., McDuff, R.E., 1992. On the partitioning of heat flux between diffuse and point source seafloor venting. J. Geophys. Res. 97 (B9), 219-314.

Schultz, A., Dickson, P., Elderfield, H., 1996. Temporal variations in diffuse hydrothermal flow at TAG. Geophys. Res. Lett. 23 (23), 3471-3474.

Shank, T.M., Fornari, D.J., Von Damm, K.L., Lilley, M.D., Haymon, R.M., Lutz, R.A., 1998. Temporal and spatial patterns of biological community development at nascent deep-sea hydrothermal vents (950'N, East Pacific Rise). Deep-Sea Res. 45, 465-515.

Shillito, B., Jollivet, D., Sarradin, P.M., Rodier, P., Lallier, F., Desbruyères, D., Gaill, F., 2001. Temperature resistance of Hesiolyra bergi, a polychaetous annelid living on deep-sea vent smoker. Mar. Ecol. Progr. Ser. 216, 141-149.

Somero, G.N., Childress, J.J., Anderson, A.E., 1989. Transport, metabolism, and detoxification of hydrogen sulfide in animals from sulfide-rich environments. CRC Critic. Rev. Aquat. Sci. 1 (4), 591-614.

Trivett, D.A., Williams, A.J., 1994. Effluent From Diffuse Hydrothermal Venting.2. Measurement Of Plumes From Diffuse Hydrothermal Vents At The Southern Juan de Fuca Ridge. J. Geophys. Res. 99 (C9), 18417-18432.

Truzzi, G. E., Sarma, G. R., Chokani, N. 2002. Constant voltage anemometer operated hot wire at subsonic speeds over wide overheats in unsteady flows. Rev. Scient. Instr. vol. $73, \mathrm{n}^{\circ}$ 12, pp. 4363-4368.

Tryon, M., Brown, K., Dorman, L., Sauter, A., 2001. A new benthic aqueous flux meter for very low to moderate discharge rates. Deep Sea Res. 48, 2121.

Tunnicliffe, V., Garrett, J.F., Johnson, H.P., 1990. Physical and biological factors affecting the behaviour and mortality of hydrothermal vent tubeworms (vestimentiferans). Deep Sea Res. 37, 103-125.

Urcuyo, I.A., Massoth, G.J., Julian, D., Fisher, C.R., 2003. Habitat, growth and physiological ecology of a basaltic community of Ridgeia piscesae from the Juan de Fuca Ridge. Deep Sea Res. 50, 763-780.

Van Dover, C.L., 1990. Biogeography of hydrothermal vent communities along seafloor spreading centers. Tree 5 (8), 242-246. 


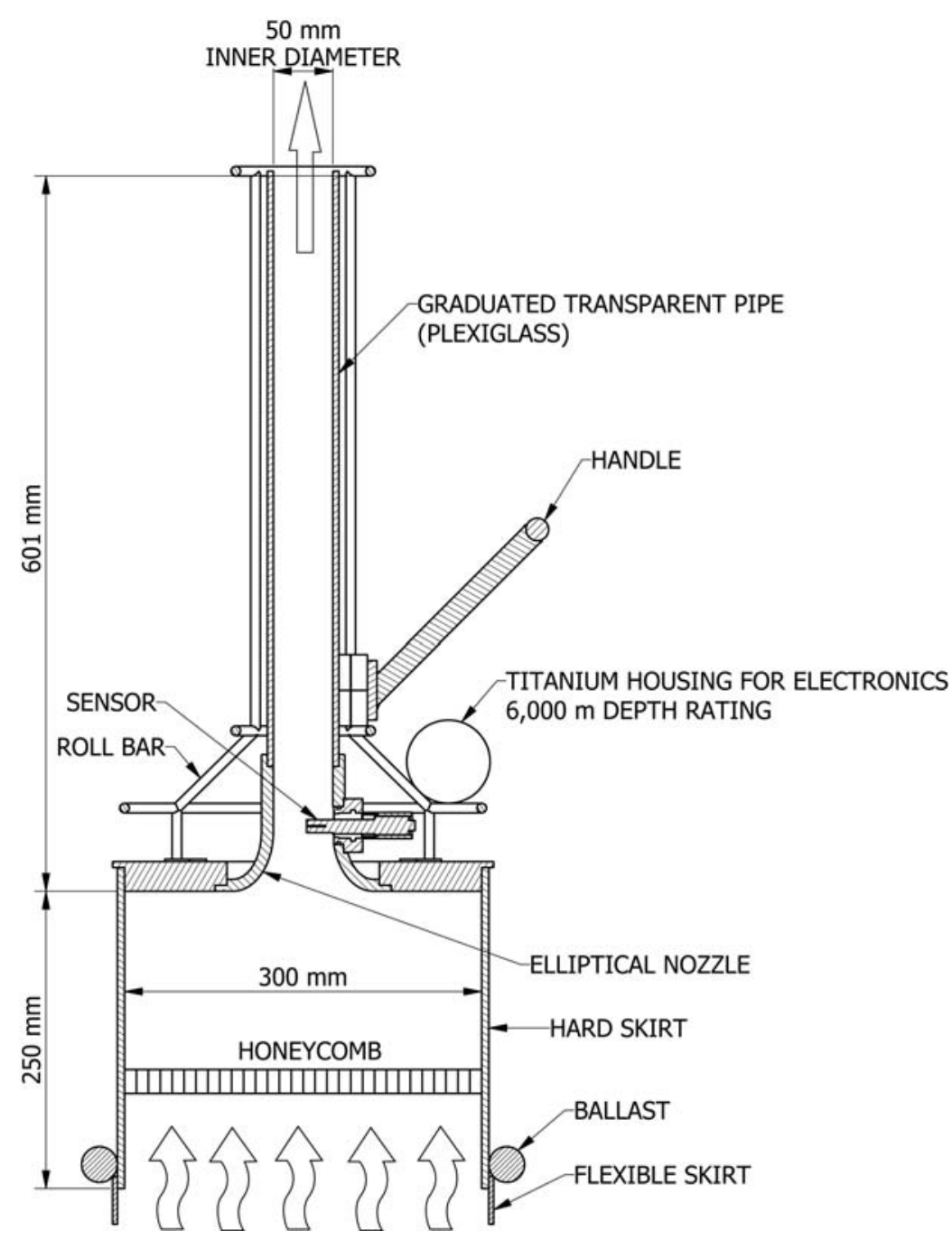

Figure 1. The flow visualizer is composed of a transparent, $2-\mathrm{cm}$ interval graduated pipe mounted on a large cylindrical chamber. 


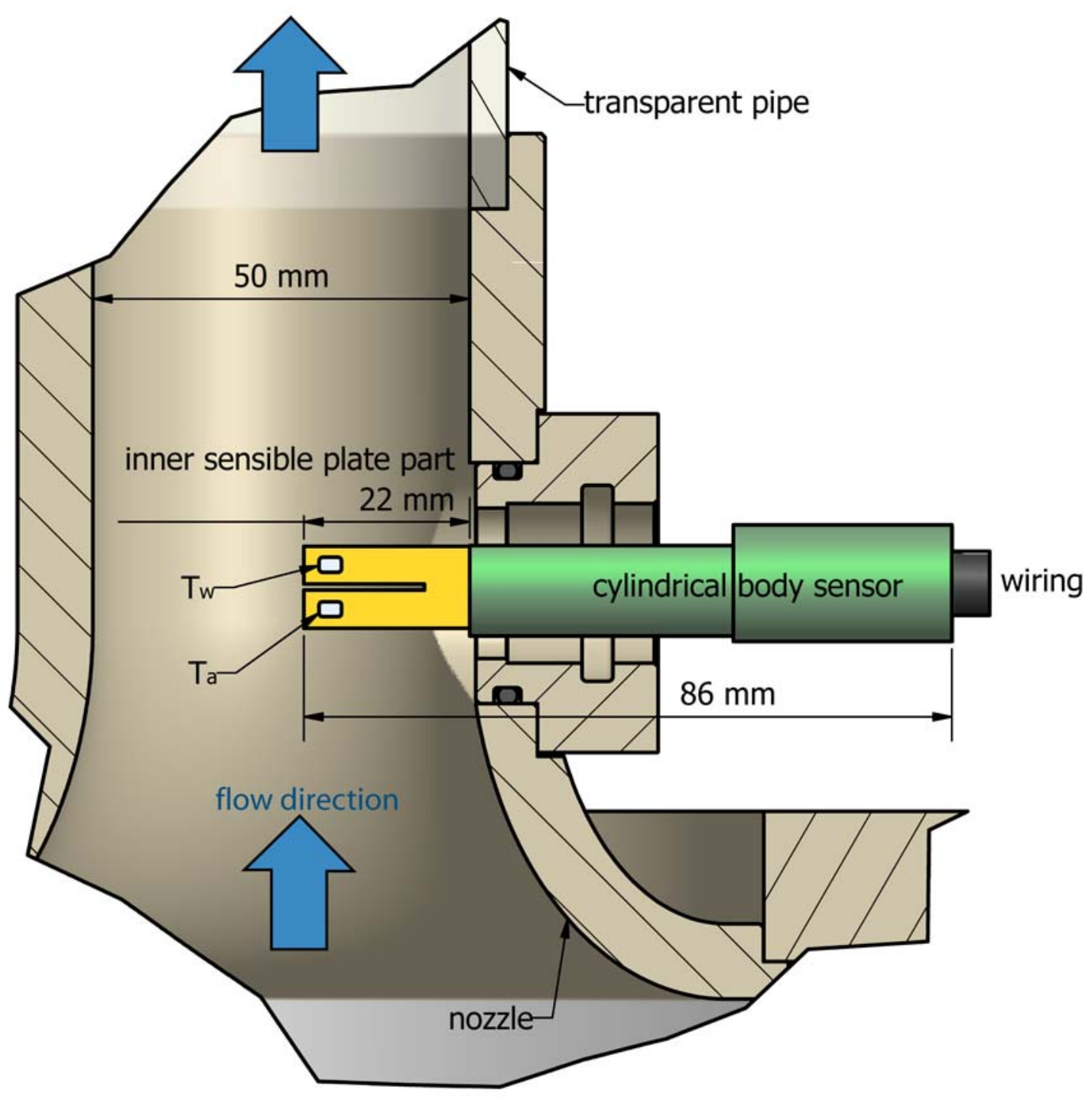

Figure 2. The flow sensor is constituted of two Pt resistive temperature sensors and a hot wire embedded in an epoxy paddle. Earth-Ocean Systems Ltd. 


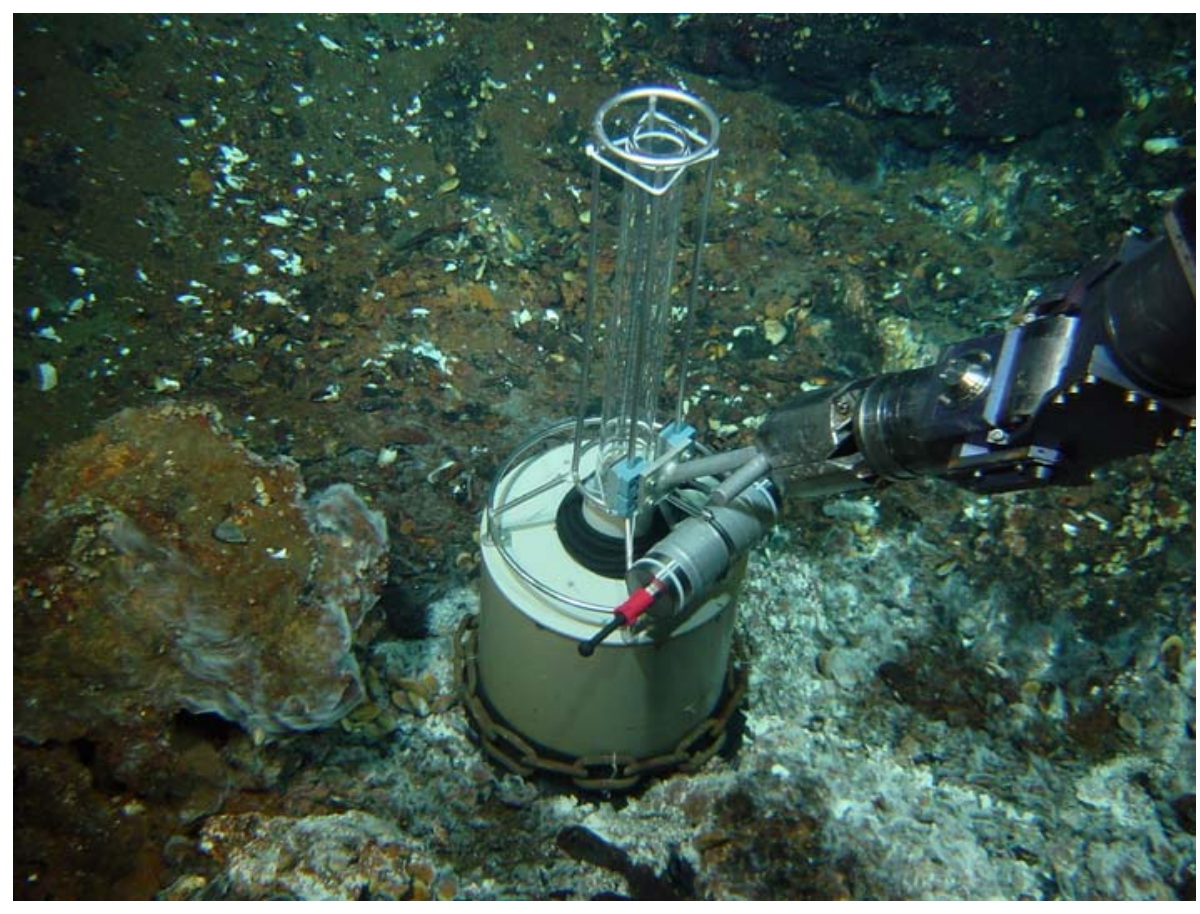

Figure 3. The dual system FLO was deployed on the Tour Eiffel hydrothermal edifice during the MoMARETO cruise in 2006. The flow rate is determined by a dual approach combining video imagery and flow sensor measurements. 


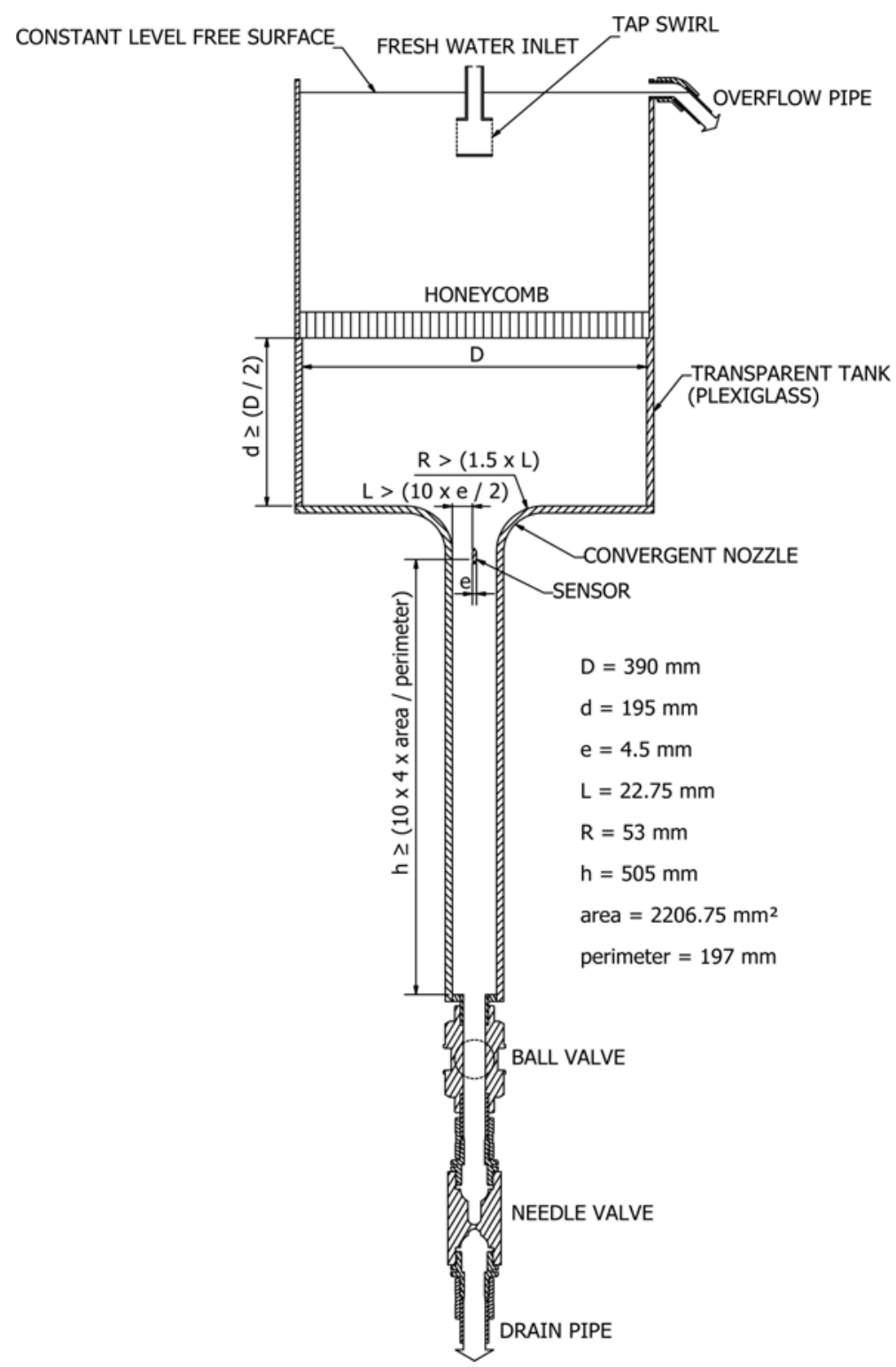

Figure 4. Scheme of the flow sensor calibration device.

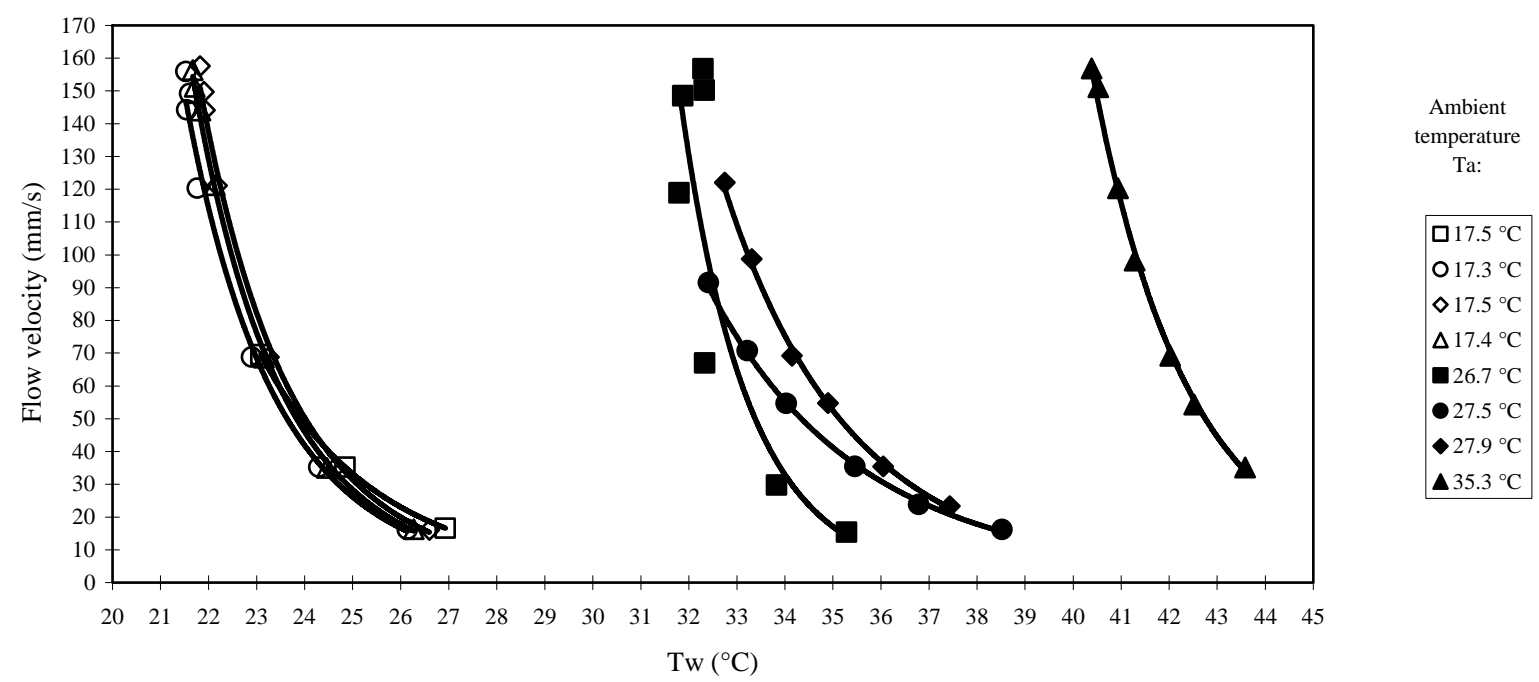


Figure 5. Applied fluid flow velocity versus hot film temperature (Tw) obtained with the flow sensor probes in the laboratory at different ambient temperatures (Ta: 17.5 to $35.3^{\circ} \mathrm{C}$ ).

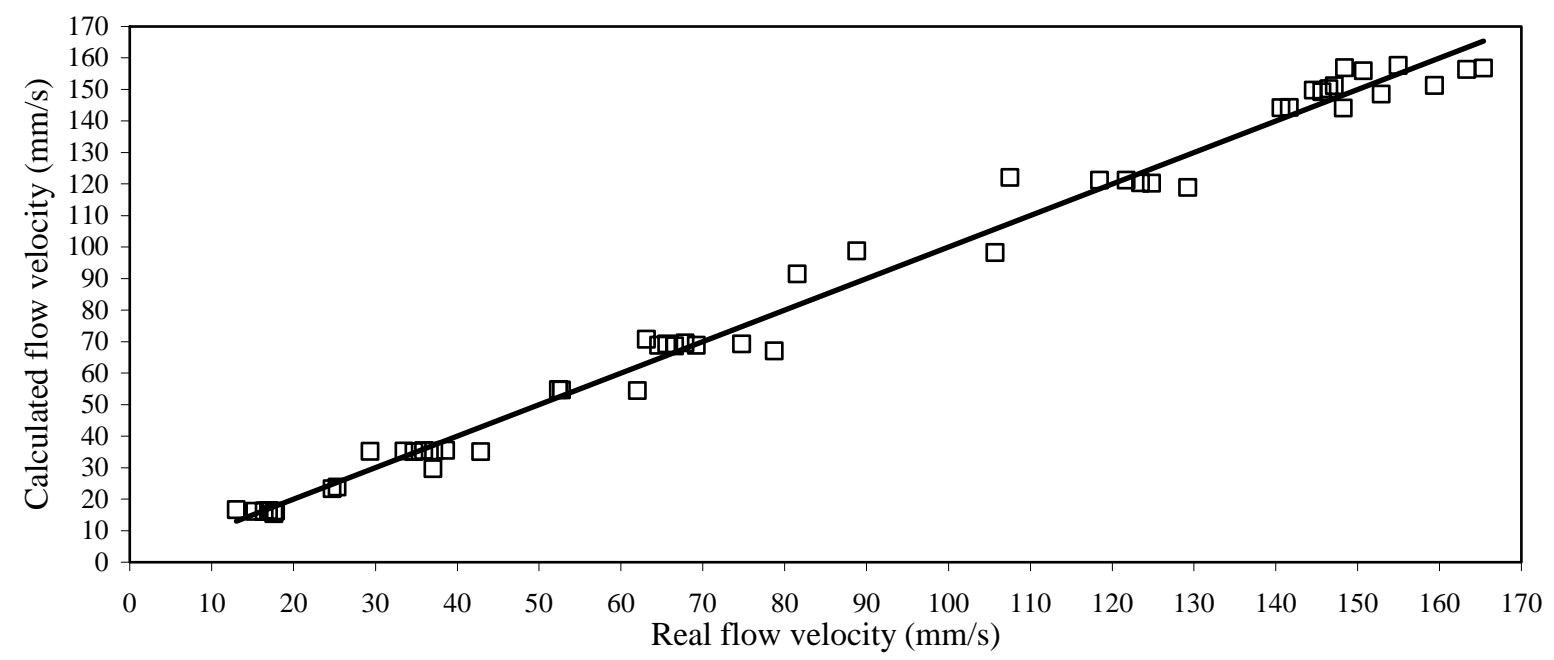

Figure 6. Calculated flow velocity $(U)$ versus real flow speed, measured in the laboratory, using the calibration model (eq. 5). The determination coefficient $R^{2}$ is 0.988 .

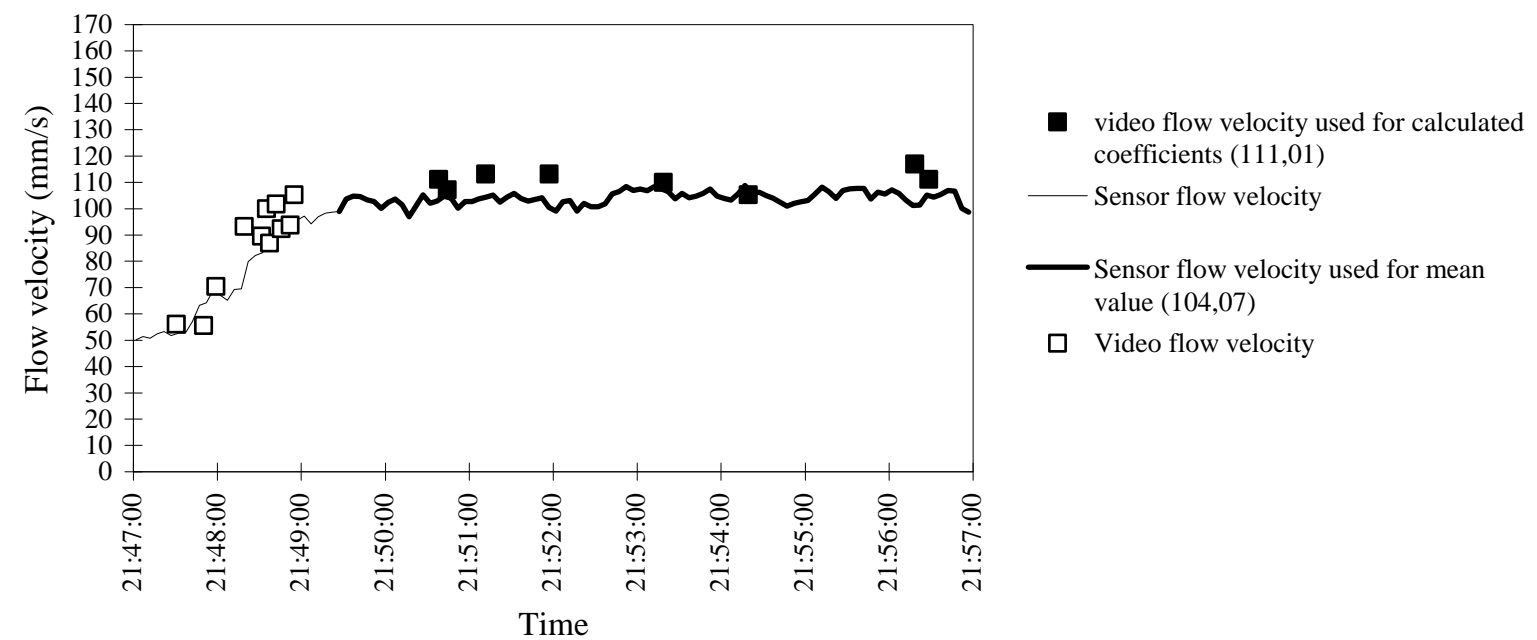

Figure 7. Fluid velocity data obtained during the fourth deployment of dive 304 during the MOMARETO cruise in 2006. The white rectangles (口) represent the flow velocities as measured by Observer 2 (OBS2) using video image analyses. To get the best "mean" possible and to limit large standard deviations, only the velocity values on the stable portion of the curve ( $\square$ ) were used to calculate the different coefficients. The bold line represents the interval used to calculate the final mean sensor flow velocity. 


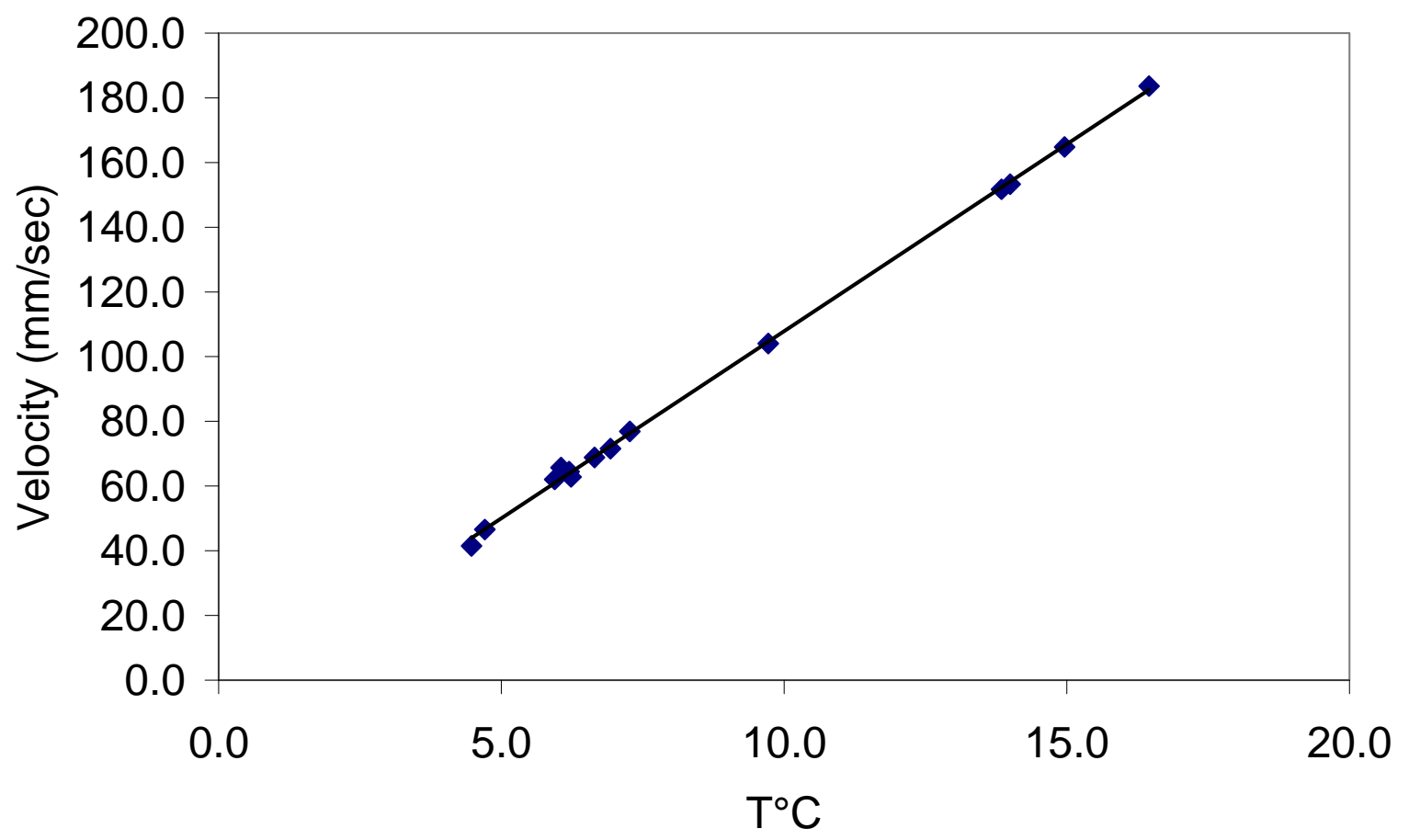

Figure 8. Mean flow velocity versus mean ambient flow temperature (Ta) as resulted from the 14 measurements on the Eiffel Tower edifice. The determination coefficient $R^{2}$ is 0.999 for a total number of measurements $(n)$ of 14 . The following equation: Velocity $=11.566 \mathrm{Ta}-$ 7.8433 where $\mathrm{Ta}$ is the ambient flow temperature $\left({ }^{\circ} \mathrm{C}\right)$ describes a best fit to the velocity data. 
Table 1. Paired comparisons of fluid flow velocities as measured by three different observers for 6-9 different video sequences. Test 1: Wilcoxon signed rank test for difference in the mean velocity for all particles, in all paired sequences between observers. Test 2: Wilcoxon signed rank test for difference in the velocity for paired particles between observers. $V$ and $p$ values are given. * indicates that there is a statistical difference $(\alpha=0.05)$ between two observers.

\begin{tabular}{|c|c|c|c|}
\hline Wilcoxon signed rank test & OBS1 & OBS1 & OBS2 \\
\hline \multicolumn{4}{|l|}{ Test 1} \\
\hline $\mathrm{n}$ sequences & 9 & 6 & 6 \\
\hline V & 15 & 0 & 0 \\
\hline P-values & 0.4258 & $0.03125^{\star}$ & $0.03125^{\star}$ \\
\hline \multicolumn{4}{|l|}{ Test 2} \\
\hline n particles & 104 & 93 & 37 \\
\hline V & 1725.5 & 1216.5 & 296 \\
\hline P-values & 0.1077 & 0.8814 & 0.3519 \\
\hline
\end{tabular}


Table 2. Temperature and flow measurements acquired during three dives of the MOMARETO cruise. The approximate duration of each sequence is given. The video flow velocity was extracted from video image analyses. $T a$ and $T w$ are respectively the ambient and the hot film temperature measured by the flow sensor. The flow velocity at the sensor level is obtained using equation 6 . The mean flow velocity at the substratum level was estimated by dividing the velocity at the sensor level by 37.6 (representing the ratio between the surface area of the chamber $\left(706.9 \mathrm{~cm}^{2}\right)$ and that of the pipe $\left(18.8 \mathrm{~cm}^{2}\right)$. The flow rate is directly calculated by multiplying the sensor flow velocity with the cross-sectional area at the sensor level divided by the studied surface area: flow velocity sensor $(\mathrm{dm} / \mathrm{min}) \times$ pipe surface area $\left(\mathrm{dm}^{2}\right) /$ chamber surface area $\left(\mathrm{m}^{2}\right)$. SD corresponds to standard deviation.

\begin{tabular}{|c|c|c|c|c|c|c|c|}
\hline Dive & $\begin{array}{c}\text { Duration } \\
(\min \pm 0.5 \mathrm{~s})\end{array}$ & $\begin{array}{c}\text { Video flow } \\
\text { velocity } \\
\left(\mathrm{mm} \mathrm{s}^{-1}\right) \pm \mathrm{SD}\end{array}$ & $\begin{array}{c}\mathrm{Ta}\left({ }^{\circ} \mathrm{C}\right) \\
\pm \mathrm{SD}\end{array}$ & $\begin{array}{c}\operatorname{Tw}\left({ }^{\circ} \mathrm{C}\right) \\
\pm \mathrm{SD}\end{array}$ & $\begin{array}{l}\text { Flow velocity at } \\
\text { the sensor level } \\
\left(\mathrm{mm} \mathrm{s}^{-1}\right) \pm \mathrm{SD}\end{array}$ & $\begin{array}{c}\text { Mean flow } \\
\text { velocity at the } \\
\text { substratum } \\
\text { level } \\
\left(\mathrm{mm} \mathrm{s}^{-1}\right) \pm \mathrm{SD}\end{array}$ & $\begin{array}{c}\text { Flow rate } \\
\left(\mathrm{L} \mathrm{min}^{-1} \mathrm{~m}^{-2}\right) \\
\pm \mathrm{SD}\end{array}$ \\
\hline \multirow[t]{5}{*}{301} & 17 & $161.5 \pm 12.5$ & $15.0 \pm 0.6$ & $18.9 \pm 0.5$ & $164.8 \pm 6.8$ & $4.4 \pm 0.2$ & $262.9 \pm 10.8$ \\
\hline & 10 & & $16.4 \pm 0.3$ & $20.0 \pm 0.3$ & $183.6 \pm 4.5$ & $4.9 \pm 0.1$ & $293.0 \pm 7.1$ \\
\hline & 2 & & $4.7 \pm 0.1$ & $9.3 \pm 0.2$ & $46.6 \pm 1.6$ & $1.2 \pm 0.1$ & $74.3 \pm 2.5$ \\
\hline & 7 & & $6.9 \pm 0.2$ & $11.4 \pm 0.3$ & $71.6 \pm 2.6$ & $1.9 \pm 0.1$ & $114.2 \pm 4.1$ \\
\hline & 6 & $151.9 \pm 9.5$ & $13.8 \pm 0.5$ & $17.5 \pm 0.4$ & $151.7 \pm 5.9$ & $4.0 \pm 0.2$ & $242.0 \pm 9.4$ \\
\hline \multirow[t]{5}{*}{302} & 8 & $61.1 \pm 9.8$ & $6.2 \pm 0.2$ & $11.0 \pm 0.3$ & $64.4 \pm 2.9$ & $1.7 \pm 0.1$ & $102.8 \pm 4.6$ \\
\hline & 10 & & $4.5 \pm 0.1$ & $8.7 \pm 0.3$ & $41.9 \pm 1.8$ & $1.1 \pm 0.1$ & $66.2 \pm 2.9$ \\
\hline & 2.5 & & $14.0 \pm 0.6$ & $17.9 \pm 0.6$ & $153.3 \pm 6.7$ & $4.1 \pm 0.2$ & $244.6 \pm 10.7$ \\
\hline & 2 & & $6.6 \pm 0.1$ & $11.2 \pm 0.1$ & $68.8 \pm 1.1$ & $1.8 \pm 0.1$ & $109.8 \pm 1.8$ \\
\hline & 10 & $67.7 \pm 10.4$ & $6.2 \pm 0.2$ & $10.6 \pm 0.4$ & $62.8 \pm 3.2$ & $1.7 \pm 0.1$ & $100.2 \pm 5.1$ \\
\hline \multirow[t]{4}{*}{304} & 0.5 & $64.2 \pm 1.5$ & $6.1 \pm 0.2$ & $11.3 \pm 0.2$ & $65.7 \pm 2.0$ & $1.7 \pm 0.1$ & $104.8 \pm 3.1$ \\
\hline & 7 & $56.8 \pm 6.2$ & $5.9 \pm 0.2$ & $10.8 \pm 0.3$ & $62.0 \pm 2.1$ & $1.6 \pm 0.1$ & $99.0 \pm 3.4$ \\
\hline & 8 & $77.9 \pm 5.2$ & $7.3 \pm 0.1$ & $12.1 \pm 0.3$ & $76.9 \pm 1.8$ & $2.0 \pm 0.1$ & $122.7 \pm 2.8$ \\
\hline & 7.5 & $111.0 \pm 3.7$ & $9.7 \pm 0.2$ & $14.3 \pm 0.2$ & $104.1 \pm 2.5$ & $2.8 \pm 0.1$ & $166.0 \pm 4.1$ \\
\hline
\end{tabular}


Table 3: Review of fluid flow velocities measured in different deep-sea chemosynthetic ecosystems. Modified from Ramondenc et al. (2006). * Equivalent to measurement at sensor level, not calibrated for surface or no information on calibration. ${ }^{* \star}$ Equivalent to measurement at substratum level.

\begin{tabular}{|c|c|c|c|c|c|c|}
\hline Authors & Sites & $\begin{array}{l}\text { Type of } \\
\text { emission }\end{array}$ & Methods & $\mathbf{T}^{\circ} \mathrm{C}$ & $\begin{array}{c}\text { Flow } \\
\text { velocity } \\
\mathrm{mm} \mathrm{s}^{-1} \\
\end{array}$ & Flow rate \\
\hline $\begin{array}{c}\text { Corliss et al. } \\
1979\end{array}$ & Galapagos & Vents & $\begin{array}{l}\text { Visual observation } \\
\text { on a vane-type } \\
\text { flowmeter }\end{array}$ & & & $2-10 L^{-1} s^{-1}$ \\
\hline $\begin{array}{l}\text { Converse et } \\
\text { al. } 1984\end{array}$ & EPR $21^{\circ} \mathrm{N}$ & $\begin{array}{l}\text { Hot vents and } \\
\text { chimneys }\end{array}$ & Turbine flowmeter & $275-350$ & $700-2400^{*}$ & $150 \mathrm{~kg} \mathrm{H}_{2} \mathrm{O} \mathrm{s}^{-1}$ \\
\hline $\begin{array}{l}\text { Rona and } \\
\text { Trivett, } 1992\end{array}$ & $\begin{array}{c}\text { Juan de } \\
\text { Fuca Ridge }\end{array}$ & $\begin{array}{c}\text { Discrete } \\
\text { sources } \\
\text { Diffuse } \\
\text { sources }\end{array}$ & $\begin{array}{l}\text { Visual, eddies and } \\
\text { particles tracking }\end{array}$ & $\begin{array}{l}108-326 \\
21-226\end{array}$ & $\begin{array}{l}250-900 * \\
50-100 *\end{array}$ & \\
\hline $\begin{array}{c}\text { Schultz et al. } \\
1992\end{array}$ & $\begin{array}{c}\text { Juan de } \\
\text { Fuca Ridge }\end{array}$ & $\begin{array}{l}\text { Diffuse flow } \\
\text { (tubeworms) }\end{array}$ & $\begin{array}{l}\text { Electromagnetic } \\
\text { induction flow } \\
\text { meter, time series }\end{array}$ & $7-13$ & $70-150 * *$ & \\
\hline $\begin{array}{c}\text { Ginster et al. } \\
1994\end{array}$ & $\begin{array}{c}\text { Juan de } \\
\text { Fuca Ridge }\end{array}$ & $\begin{array}{l}\text { Hot vents } \\
\text { chimneys }\end{array}$ & Turbine flowmeter & $\begin{array}{l}296-374 \\
235-350 \\
\end{array}$ & $\begin{array}{c}600-6200 \\
1300-3500\end{array}$ & \\
\hline $\begin{array}{c}\text { Schultz et al. } \\
1996\end{array}$ & $\begin{array}{l}\text { TAG Mid- } \\
\text { Atlantic } \\
\text { Ridge } \\
\end{array}$ & $\begin{array}{l}\text { Diffuse flow } \\
\text { Time series }\end{array}$ & $\begin{array}{l}\text { Medusa (titanium } \\
\text { rotor velocity } \\
\text { sensor) } \\
\end{array}$ & $14 \pm 0.5$ & $5.1 \pm 0.4^{\star \star}$ & \\
\hline $\begin{array}{l}\text { Ramondenc } \\
\text { et al. } 2006\end{array}$ & $\begin{array}{c}\text { EPR 950' } \\
N\end{array}$ & $\begin{array}{c}\text { High } \\
\text { temperature } \\
\text { venting sites } \\
\text { Low } \\
\text { temperature } \\
\text { diffuse venting } \\
\text { sites } \\
\end{array}$ & $\begin{array}{l}\text { Visual, eddies and } \\
\text { particles tracking }\end{array}$ & $\begin{array}{c}345-388 \\
10\end{array}$ & $\begin{array}{c}100-300^{\star} \\
40^{\star}\end{array}$ & \\
\hline This study & LS- MAR & $\begin{array}{c}\text { Low } \\
\text { temperature } \\
\text { diffuse } \\
\text { venting sites } \\
\end{array}$ & $\begin{array}{l}\text { Visual and } \\
\text { heated thin film } \\
\text { flow sensor }\end{array}$ & $\begin{array}{l}4.7- \\
16.4\end{array}$ & $\begin{array}{l}42-184^{*} \\
1.1-4.9^{* *}\end{array}$ & $\begin{array}{c}66-293 \\
L \mathrm{~min}^{-1} \mathrm{~m}^{-2}\end{array}$ \\
\hline \multicolumn{7}{|l|}{ Seeps } \\
\hline $\begin{array}{l}\text { Linke et al. } \\
1994\end{array}$ & $\begin{array}{l}\text { Cascadia } \\
\text { margin }\end{array}$ & & $\begin{array}{l}\text { Mechanical mass } \\
\text { flow meter } \\
\text { thermistor hot } \\
\text { bead flowmeter }\end{array}$ & & $\begin{array}{l}0.5-10 \\
\text { (measured } \\
\text { by the } \\
\text { sensor) }\end{array}$ & $\begin{array}{c}30-1065 \mathrm{~m} \mathrm{yr}^{-1} \\
\left(\mathrm{max} 0.03 \mathrm{~mm} \mathrm{~s}^{-}\right. \\
\left.{ }_{1}\right)\end{array}$ \\
\hline $\begin{array}{c}\text { Tryon et al. } \\
2001\end{array}$ & $\begin{array}{l}\text { Cascadia } \\
\text { margin }\end{array}$ & & $\begin{array}{c}\text { Chemical and } \\
\text { aqueous transport } \\
\text { meter }\end{array}$ & & $10-\underset{\mathrm{yr}^{-1}}{200 \mathrm{~cm}}$ & \\
\hline
\end{tabular}

